VIII-1 | 2016

Dewey's Democracy and Education as a Source of and a Resource for European Educational Theory and Practice

\title{
Daniel MORENO, Santayana the Philosopher. Philosophy
} as a Form of Life

[translated by Charles Padron], Lewisburg, PA, Bucknell University Press, 2015, 195 pages

Nóra Horváth

\section{OpenEdition}

\section{Journals}

Electronic version

URL: http://journals.openedition.org/ejpap/473

DOI: 10.4000/ejpap.473

ISSN: 2036-4091

Publisher

Associazione Pragma

Electronic reference

Nóra Horváth, «Daniel moreno, Santayana the Philosopher. Philosophy as a Form of Life », European

Journal of Pragmatism and American Philosophy [Online], VIII-1 | 2016, Online since 20 July 2016, connection on 24 September 2020. URL : http://journals.openedition.org/ejpap/473 ; DOI : https:// doi.org/10.4000/ejpap.473

This text was automatically generated on 24 September 2020

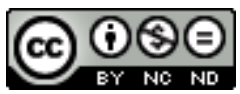

Author retains copyright and grants the European Journal of Pragmatism and American Philosophy right of first publication with the work simultaneously licensed under a Creative Commons AttributionNonCommercial-NoDerivatives 4.0 International License. 


\section{Daniel MORENO, Santayana the Philosopher. Philosophy as a Form of Life}

[translated by Charles Padron], Lewisburg, PA, Bucknell University Press, 2015, 195 pages

Nóra Horváth

\section{REFERENCES}

Daniel Moreno, Santayana the Philosopher. Philosophy as a Form of Life, [translated by Charles Padron], Lewisburg, PA, Bucknell University Press, 2015, 195 pages

1 George Santayana is not one of the most famous, yet one of the few whose huge oeuvre offers different ways to explain his main notions in connection with a number of possible topics within philosophy. At first sight it takes a real challenge to choose Santayana as a central topic in contemporary research but later one can realize that the spaciousness of the Santayanan oeuvre can provide new opportunities of its interpretation in every time. Daniel Moreno with his doctoral dissertation on Santayana and later with the first, Spanish version of his Santayana the Philosopher (Santayana filósofo. La filosofia como forma de vida) proves that there is something in Santayana that would be or can be interesting in the 21st century too. Moreno gives an incredibly rich survey about the main characteristics of Santayana's philosophy, but his book is more than a simple historical treatise, because he follows the conception of those philosophers who consider philosophy as life-practice, as a possible "form of life."

2 Moreno's work displays a precisely shaped conception of the unity of Santayana's life and work, and he confirms from the first pages to the end that we have to treat Santayana's works - poems, novel, essays, philosophical writings - and life together as an oeuvre. I have to confess that I strongly sympathize with his conception. 
Contemporary researchers of philosophy as art of living or philosophical living give an advantage to new approaches in studying Santayana. It is not a secret that Santayana's philosophy has its roots in the ancient Greece, where philosophy was generally regarded as the crucial directive in one's life. Contemporary theories, those of $\mathrm{M}$. Foucault and A. Nehamas, affirm the importance of the role of self-writing and they suggest that philosophy be seen as a way of life. Within such a context, Moreno's book is a new contribution to this kind of philosophy.

3 Moreno read Santayana's latest works first and after reading Irving Singer's George Santayana: Literary Philosopher ${ }^{1}$ he tried to see Santayana from a different point of view, regarding him as a poet too. Thus, the early works of Santayana found Moreno in the moment when he was already trained by Santayana's style and the structure of notions and concepts. I think that this order has a crucial importance on Moreno's book and views. He considers philosophy as a form of life but he does not mention aesthetic features in it, or the ethical ideal of aesthetic living (as Foucault in connection to ancient Greek practices, or R. Shusterman in connection to the philosophy of Foucault). Santayana denied every attempt to isolate aethetics; he felt that aesthetic interest is not separable from many other interests and he created an aesthetic ontology. There is no place to Santayana's paradoxical feelings towards aesthetics in Moreno's book, thus he does not treat the importance of imagination in Santayana's early writings. The examination of The Last Puritan in the Chapter 4 can compensate us somehow for the lack of discussing aesthetic problems. One can see here that Moreno recognizes sensitively the aesthetically valuable features of Santayana's novel. I have a feeling that Chapter 4 is the most important chapter for supporting Moreno's claim formulated in the Introduction where he concludes that "one needs to read Santayana from the inside" (xxi). Chapter 4 on Santayana's novel is the realization of the pursuit of this characteristic method of Moreno. According to Moreno in The Last Puritan "Santayana can critique transcendentalism as much as Platonism from the inside, from within" (132). And I am sure that Moreno can examine Santayana in the best way "from the inside" through The Last Puritan. Though Moreno says that "there is a general consensus among his [Santayana's] critics that [A General Confession] is the best exposition of the person he was," Moreno later adds that an autobiography is not the proper way to reconstruct the author's private world. Instead of the turmoiled memories, there are other tools to reveal one's personal feelings or thoughts. In accordance with Santayana, Moreno emphasizes that The Last Puritan "belongs, together with Dialogues in Limbo, its literary cousin, as much as for its dialogic structure as for its tackling the intellectual status of illusion, to the Santayanan oeuvre in which Santayana is assertive in showing up without a mask" (130). Singer mentioned in his book that Horace M. Kallen considered The Last Puritan as the true image of Santayana and that Persons and Places was only a shield. Moreno refers to the thin fence between reality and fiction very often and suggests that the limit between them is not truly important: "what is considered real is in part invented and the invented is in part real" (127) - says Moreno in connection with Santayana's opinion in Interpretations of Poetry and Religion. Santayana's letters confirm the importance of such an approach. He was aware that he invested in The Last Puritan everything that he knew and thus his novel was more than a literary work (130).

4 Chapter 4 (entitled exactly Philosophy and Novel in the Last Puritan) is the link to Chapter 1 (Philosophy as a Form of Life) - (with a retrospective effect) and an important antecedent to Chapter 5 (Spiritual Testament). The interconnections would be 
demonstrable with a title: How to love in barbaric times? But instead of this, in the last chapter Moreno asks: How to live in barbaric times? This subchapter gives a perfect analysis of different kinds of love in Santayana's works and I think Moreno has very important observations here about love and friendship. We do not have to forget that these are the main social links among people in The Last Puritan too. Thus the refined analysis on the ideal and real love in the end of Moreno's book (157) shouts for a central place where Moreno discusses Oliver's strange attitude towards love. It is not difficult to find an interesting link between Oliver's dilemma on love and Santayana's philosophical questions in The Libertine. Moreover, the philosophical problem of the ideal and the real is a continually returning subject in Santayana's writings, in connection with Dante, Lucretius, and Michelangelo, not to mention different parts of The Sense of Beauty on love. Chapter 1 and 5 give a frame to Moreno's picture of Santayana and within the limits of a personal philosophy and a spiritual testament Moreno is able to display every thread of Santayana's thoughts linked in his crucial terms like "essence, metaphysics, religion, matter, and spirit" (xxii). It is obvious that Moreno agrees with Mossie M. Kirkwood, Anthony Woodward, and Henry Levinson that spiritual is an essential element in Santayana.

"I think this is the appropriate assessment" - says Moreno (145). This definitive opinion revealed itself in Moreno's declaration on The Last Puritan too when he says that the "particular relation between reality and fiction connects directly with the point of view of the spirit, as it is presented in The Realm of Spirit. From the perspective that it reaches, history, truth, fiction, and illusion are all situated in the same level" (127). Through Moreno's examination of Santayana one can realize that the opposition of terms like ideal and real, or ancient and modern can offer a good philosophical net to keep the seemingly controversial but complementary ideas of Santayana's philosophy. "My own line of argument in this book supports the view that Santayana was a thinker who was an heir to modern thought [...]. The criticism of science and liberalism, the growing prominence that the spiritual acquires in his oeuvre, and the search for alternatives in Oriental and Hellenistic traditions are symptoms of a personal choice in the face of what is experienced as the disintegration of the modern world. Given this situation, Santayana maintained a characteristic spiritual equanimity and detachment, with few disturbances, which became so enviable and untenable for other individuals" (23) says Moreno and he does not want to put Santayana into strict categories. He has eyes to every little nuance of Santayana's terminology and keeps in mind his own conscious unifying method. For example, in the first chapter Moreno accurately scrutinizes every label that usually hinders the objective examination of Santayana's philosophy. Descriptions of ironic nihilism, Platonic materialism and spiritual atheism give the fundamental tone to the whole book.

5 According to Moreno, Santayana can be a "philosophical bridge between Europe and the United States." Moreno wants to show a Spanish point of view to the audience in his book but (because of the fact that the Spanish Santayana wrote in English) the exclusive knowledge of the Spanish cultural background would not be enough to reveal every meaning of Santayana's texts. In Santayana's philosophical heritage ("on the one side") there is "William James and John Dewey; on the other side, Lucretius and Spinoza" (xi). According to this, there is another possible role to Santayana: being a philosophical bridge between past and present. Affirming this Moreno insists that Santayana opposed to dominant opinions of his own age. For example, he showed "quietude in the face of agitation," "peace in the face of vanity" and "simplicity in the 
face of complexity" (3). These attitudes are in a close relation with Santayana's political behaviour. In my view mentioning thinkers like John Henry Newman is one of the strengths of Moreno's book. And that is why the Spanish point of view is not enough to examine Santayana's ideological choices. "Santayana furthered the work of such menof-letters as Thomas Carlyle and John Henry Newman with his Oxford Movement who, in the nineteenth century, were active critics of liberalism and industrialization for the bankrupt spiritual values associated with them, and who defended a Catholic Conception of Anglicanism..." - says Moreno (95). The appreciation of Newman means the same to Oscar Wilde and to Santayana. They had the same opinion on Newman's educational ideal that linked past and present and gave a hopeful strategy to every contemplative mind that felt some aversion towards modernity, industrialization and aggressive utility. Moreno mentions Newman under the title "Political Philosophy" but I have a strong feeling that Newman's ideal of education has a closer relation to Santayana's views. I lack the presentation of Newman's thoughts on the ideal attitude because somehow Santayana's lifestyle was an exemplification of Newman's recipe. In 1864 in the Apologia Pro Vita Sua Newman emphasized the advantages of contemplative attitude, knowledge for its own sake and retiring from the world as positive choices in modern times. It was Newman's respect towards the ancient philosophers (and not only his Christianity) that lays the foundation of his movement and thus Newman became the hero of a cult that turned against modernism. Moreno doesn't mention that in Santayana's antipathy towards the American values there is his negative judgment of American universities and his motivation was the same as Newman's who supported the rebirth of ancient virtues in modern education - Newman was an advocate of ancient values, and most of these values were Platonic. And here is another topic that would provide another occasion to rethink Santayana's many-sided oeuvre that could be seen as a unity if we assume Moreno's point of view. We do not have to forget the title of Moreno's book: he does not want to leave any doubt that Santayana was a philosopher and (as I mentioned earlier) Moreno asserts that philosophy as a form of life must have its place within serious philosophical treatises.

6 At the end of Moreno's book there is a rich listing of secondary sources and another selection of Spanish-language sources. One could have the feeling that Moreno read everything from and about Santayana in Spanish and in English too. His intention has substantiated: "There I read [in Zaragoza] and in English, under the sound guidance of Ignacio Izuzquiza Otero (University of Zaragoza) - all that Santayana had ever written. This was a task apparently not too laborious but one that obscured a very difficult effort indeed: to become familiar with all the sources both primary and secondary, in English as well as Spanish - and this is perhaps one of the strongest points of my focus" (x). Thanks to Charles Padron's translation, the result of Moreno's huge research can be a part of the international discourse on Santayana.

\section{NOTES}

1. New Haven, Yale University Press, 2000. 


\section{AUTHORS}

NÓRA HORVÁTH

Széchenyi István University, Hungary

horvath.nora[at]sze.hu 